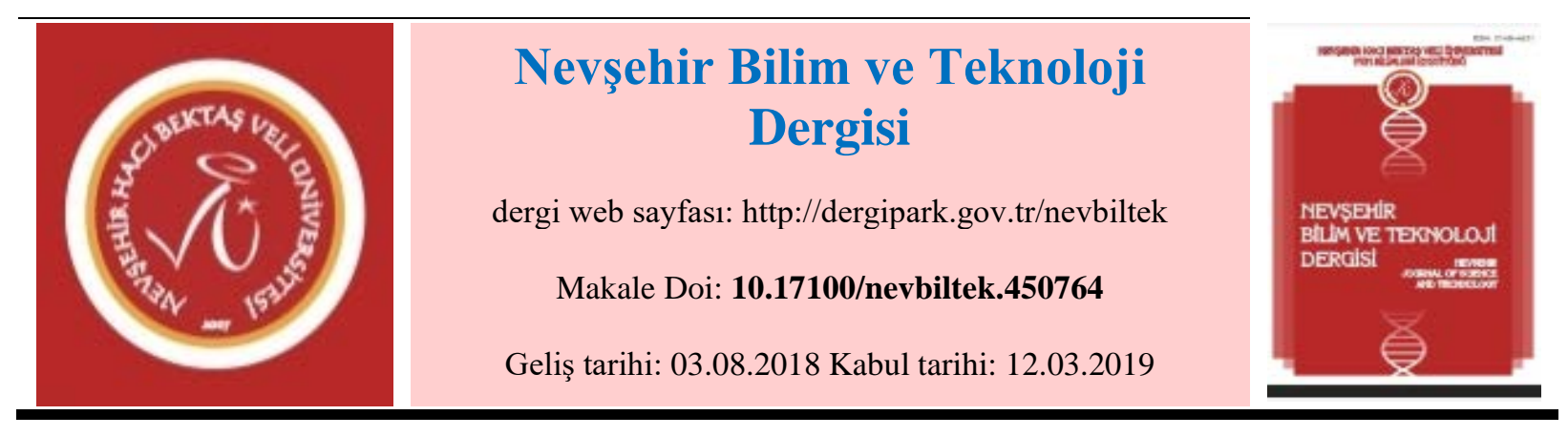

\title{
Moleküler Toksikoloji ve “Omik” Teknolojileri ${ }^{1}$
}

\author{
Ceren BÖRÇEK KASURKA ${ }^{1}$ \\ ${ }^{1}$ Ordu Üniversitesi, Fen Edebiyat Fakültesi, Moleküler Biyoloji ve Genetik Bölümü, Ordu \\ ORCID ID: 0000-0002-5772-9463
}

Öz

Toksikoloji, bir organizmada kimyasal, fiziksel veya biyolojik ajanlara maruziyetin sebep olduğu fenotipik değişiklikleri araştırır. Moleküler toksikoloji ise çeşitli malzemelerin, ilaçların, kimyasal maddelerin, toksinlerin ve benzeri maddelerin fonksiyonel mekanizmalarının anlaşılması için moleküler ve hücresel biyolojinin, hücresel ve biyokimyasal seviyelerde kullanıldığı araştırmaları kapsamaktadır. 1980'lerde moleküler biyoloji araçlarının geliştirilmesine paralel olarak, toksikoloji dahil olmak üzere biyolojik bilimlerde bir dönüşüm başlamıştır. Aynı zamanlarda yayınlanan, "Toksikoloji molekülere kaymaktadır" başlıklı bir makale, toksikolojinin yaşanan çağdaki gelişmelere uyum sağlamakta olduğunu göstermektedir. Bu gelişmelerin ardından toksikologlar, zehirli bir maddenin DNA'nın yapısı, fonksiyonu ve (hedef) gen ekspresyonu üzerindeki etkilerini araştırabilir, toksik cevabı düzenleyen genleri klonlayabilir ve "omik" teknolojilerden (genomik, proteomik, metabolomik, interaktomik), epigenetikten, sistem biyolojisinden, hesaplamalı bilimlerden ve in vitro biyolojiden elde edilen bilgileri harmanlayabilir hale gelmiştir. Günümüzde kullanılmakta olan 100.000 'e yakın kimyasal madde mevcuttur ve bunların sadece küçük bir kısmının toksikolojik değerlendirmesi yapılmış durumdadır. Dolayısıyla, bilim adamları bu maddeleri tespit etmek ve etkilerini belirlemek için alternatif yaklaşımlara ihtiyaç duymaktadırlar. Sonuç olarak toksikoloji, kendisini hızla daha bütünsel bir bilimsel disipline dönüştürmektedir. Bu derlemenin amacı, teknolojik gelişmeler 1şı̆̆ında toksikolojik çalışmalara genel bir bakış sunmaktır.

Anahtar Kelimeler: Toksikoloji, Moleküler toksikoloji, Toksikogenomik

\section{Molecular Toxicology and “Omics”}

\section{Abstract}

Toxicology has honed in on phenotypic alterations in an organism which result from exposure to chemical, physical, or biologic agents. The term molecular toxicology is match up to molecular and cellular biology for understanding the functional mechanisms in materials, drugs, chemicals, toxins etc., from the molecular, cellular and biochemical levels. In the past decades, in parallel with developing of molecular biology tools, a transformation started in biological sciences, including toxicology. At about the same time, an article entitled "Toxicology goes molecular" indicated molecular toxicology had adapted to the age. After that, toxicologists can investigate the effects of a suspicious substance on DNA structure, DNA function and gene expression, also it is possible to clone genes which regulate the toxic response and use the knowledge from "omics" such as genomics, proteomics, etc., epigenetics, computational science and in vitro biology. There are close to 100,000 chemicals being used and only a small fraction of these have a toxicological evaluation. Thereby, scientists need alternative approaches for screening and detecting them. Consequently, toxicology rapidly transforms itself into a more holistic scientific discipline. The aim of this study is to prepare an overview of toxicological studies in consideration of in the view of technological developments.

Keywords: Toxicology, Molecular toxicology, Toxicogenomics 


\section{Giriş}

\section{Toksin ve toksikoloji}

Organizmaya girdiğinde kimyasal etkisiyle fizyolojik görevleri bozan ve miktarına göre canlıyı öldürebilen maddeler toksin; zehir olarak bilinmektedir. "Toksik ajan" terimi, canlı organizmalarda zararlı etkilere neden olan herhangi bir maddeyi nitelemektedir. Genel olarak, ortaya çıkan etkiler kimyasal maddeye maruz kalma düzeyine bağlıdır. Yabancı kimyasallar veya başka bir ifadeyle ksenobiyotikler; ilaçlar, endüstriyel kimyasallar, pestisitler, kirleticiler, pişirilmiş gıdalardaki piroliz ürünleri, alkaloidler, ikincil bitki metabolitleri ve küfler, bitkiler ve hayvanlar tarafından üretilen toksinler gibi doğal ve üretilmiş kimyasal maddeleri kapsamaktadır. [1, 4-6]. Kimyasal maruziyetin ardından toksisitenin gelişiminde potansiyel aşamalar Şekil 1'de özetlenmiştir.

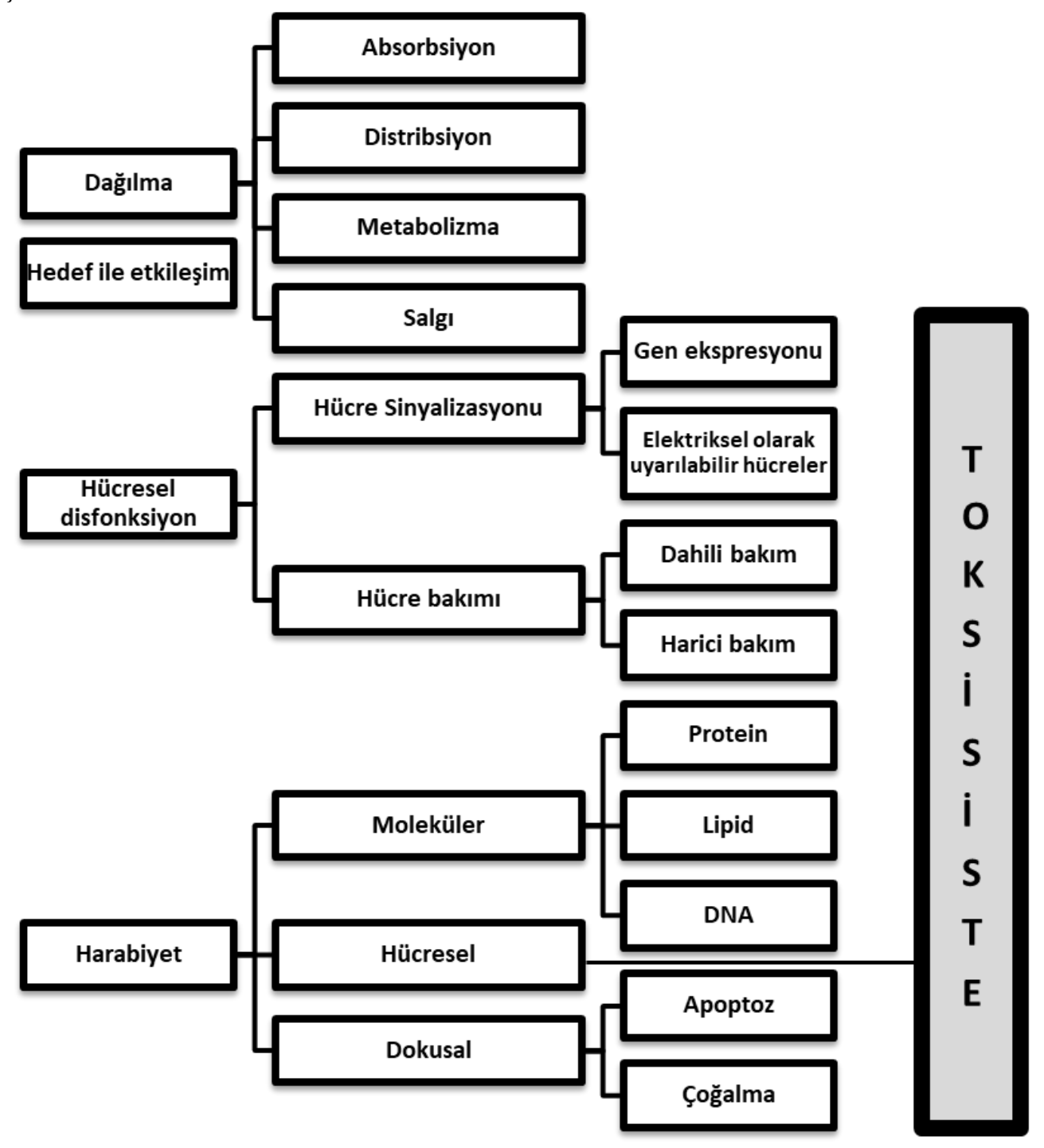

Şekil 1 Kimyasal maruziyetin ardından toksisitenin gelişiminde potansiyel aşamalar [3]'den uyarlanmıştır.

Toksikoloji, bir organizmada kimyasal, fiziksel veya biyolojik ajanlara maruziyetin sebep olduğu fenotipik değişiklikler üzerine odaklanmış bir bilim dalıdır [7]. Zehirler, kimyasal anorganik veya organik maddeler olmakla beraber hayvansal organizmaların doku ve hücreleri ile temasa geçtiklerinde ve bu doku ile organlarda uygun koşullar altında kimyasal veya fiziko-kimyasal yolla değişiklikere sebebiyet vererek sağlığ bozan veya ölüm meydana getiren maddeler olarak da tanımlanırlar [5]. İnsanoğlunun zehirle olan ilişsisi neredeyse insanlık tarihi kadar eskidir. Çeşitli bitkisel, hayvansal ya da mineral kaynaklı zehirler ilk çağlardan beri savunma veya saldırı amacıyla ya da hekimlik uygulamalarında -ve hatta politik komplolarda- 
kullanılagelmiştir. Modern toksikolojinin temelleri 19.yy'da tıp, kimya ve fizyoloji alanında çalışmalar yapan Orfila (1787-1853) tarafından atılmıştır. 20.yy’da hızla gelişme göstermeye başlayan toksikoloji I. Dünya Savaş'ının ardından bilimsel ve endüstriyel gelişmeye paralel olarak ivme kazanmıştır. 1940'lara gelindiğinde artık toksik maddelerin etkilerinin hücre, organel ve moleküler seviyede araştırılması ve etki mekanizmalarının keşfi gibi konularda önemli adımlar atılmaya başlanmıştır [4].

Klasik toksikoloji alanındaki çalışmalar, kimyasal maddeler ve fiziksel fenomenlerin canlı varlıklar ve bu varlıkların fiili mekanizmaları üzerinde patolojik değişiklikler yapabilme yeteneği üzerine odaklanmıştır. Ayrıca bu disiplin mevzubahis etkileri önleme, tespit etme, tanımlama ve hafifletme amacını da taşımaktadır. Özellikle farmasotikler söz konusu olduğunda incelenen maddeler ticarileştirilmeden önce daha ileri araştırmalara; farklı biyolojik modellerde klinik öncesi denemelere ve ardından insanlarda klinik denemelere de ihtiyaç duyulmaktadır. Klasik toksikoloji, temel olarak, belirli bir kimyasal bileşiğe maruziyet sonucu organizmada meydana gelen olumsuz etkilerin incelenmesine dayanmaktadır. Bilimin genetik kod ile biyolojik yapı ve fonksiyonu destekleyen moleküler aktivitenin temel sütunlarını keşfetmesiyle, son 50 yıllık bilimsel araştırmaların en önemli başarılarından olan genomik çağına geçiş başlamıştır. Toksikoloji alanında da genetik biliminin devreye girmesi sayesinde Paracelsus zamanlarına göre önemli bir ilerleme yaşanmıştır [1] 1980’lerde moleküler biyoloji araçlarının geliştirilmesine paralel olarak, toksikoloji dahil olmak üzere biyolojik bilimlerin birçoğunda dönüşüm başlamıştır. Aynı zamanlarda yayınlanan, "Toksikoloji molekülere kaymaktadır” başlıklı bir makale, toksikolojinin çağa uyum sağladığını açıkça göstermektedir $[1,2,8]$.

\section{Moleküler Toksikoloji}

Biyolojik sistemler; ksenobiyotik maruziyetine karşı mRNA sentezi, transdüksiyon ve hatta protein modifikasyon seviyelerinde doğrudan veya dolaylı olarak düzenlenen telafi mekanizmalarını harekete geçirerek cevap verirler. $\mathrm{Bu}$ durum, belirli gen ağlarının faaliyetlerinde artışa veya azalmaya yol açabilir. Mevzubahis mekanizmalar etkili olmadığında ise organizmalar toksik etkilere maruz kalırlar. Çeşitli malzemeler, ilaçlar, kimyasallar ve toksinler gibi maddelerin fonksiyonel mekanizmalarının moleküler, hücresel ve biyokimyasal seviyelerde anlaşılması için moleküler ve hücresel biyolojinin kullanılmasıyla yapılan araştırmalar moleküler toksikoloji alanına dahil olmaktadır $[1,9,10]$. Moleküler toksikoloji alanındaki çalışmalarda kullanılan teknikler ve moleküler hedefleri Şekil 2'de şematize edilmiştir.

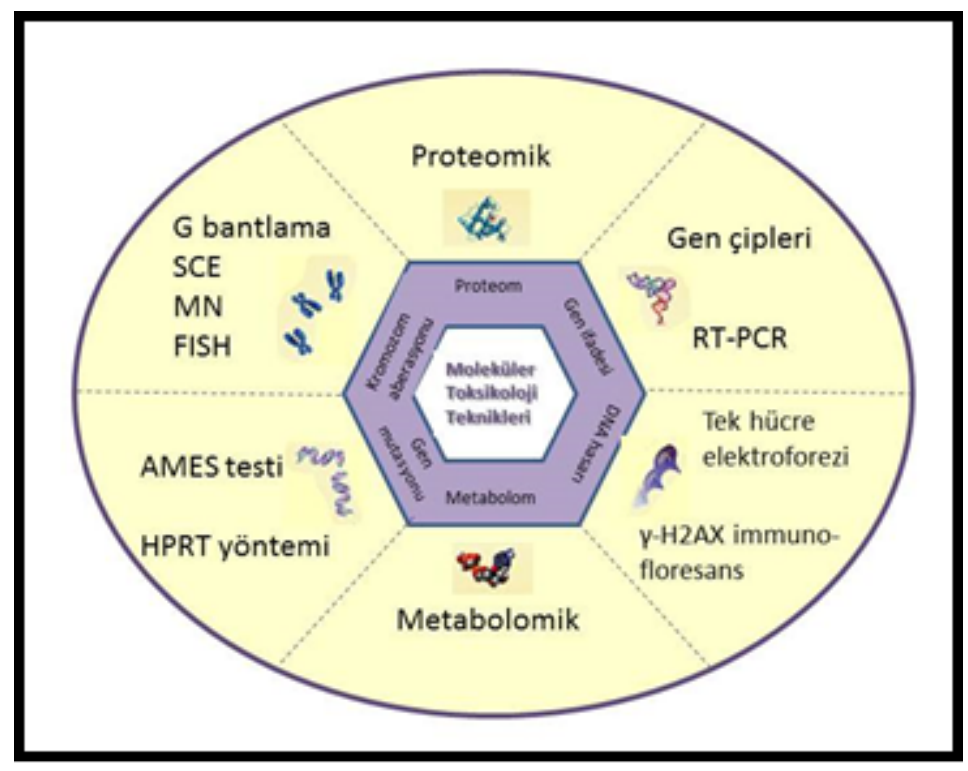

Şekil 2 Moleküler toksikoloji alanındaki çalışmalrda kullanılan teknikler ve moleküler hedefleri [2]'dan uyarlanmıştır.

Moleküler toksikoloji, doz-cevap ilişkileri ve risk tahmini de dahil olmak üzere toksikolojiye temel olan faktörlerin daha doğru belirlenmesine olanak tanıyan, algılama hassasiyetine ve yüksek verimliliğe sahip çeşitli modern teknolojileri kullanmaktadır. Moleküler toksikolojideki çalışmalar, moleküler olayların araştırılması için, floresan boya etiketli peptitler, oligonükleotidler, antikorlar gibi biyomoleküllerin yoğun şekilde kullanıldığı 
tekniklere dayanmaktadır. Moleküler toksikoloji çalışmaları sonucunda elde edilen bilgiler sadece genel toksikoloji kapsamında fayda sağlamaz. Aynı zamanda toksik maddelerin zararlı etkilerinin belirlenmesi için daha hassas ve daha doğru analizlerin geliştirilmesine de katkı sağlamaktadırlar. Ayrıca, toksik maddelerin moleküler etkileri ile hastalık gelişimi arasındaki ilişkinin aydınlatılması konusu da moleküler toksikologların çalışma sahasına girmektedir. Örneğin çeşitli kimyasalların mutajenik etkileriyle bağlantılı olan kanser tipleri düşünüldüğünde; kanserin, moleküler seviyede tümör baskılayıcıların kaybı, onkogenlerin aktivasyonu veya kontrol noktası proteinleri gibi hücre döngüsünün düzenlenmesinde rol oynayan faktörlerdeki bozukluklardan köken aldığg düşünülmektedir [10].

İnsan genomunun dizilenmesi ve ardından dizileme teknolojilerindeki hız ve maliyet yönündeki olumlu gelişmeler, biyolojik bir sistemin belirli bir toksine karşı tepkisini hedef alan ilk gen ekspresyonu çalışmalarından yola çıkarak, toksik cevabın düzenlenmesine doğrudan müdahale eden proteinlerle ilgili basit veya karmaşık gen ağlarının keşiflerini mümkün hale getirmiştir [1, 11].

Günümüzde RNA'lar, DNA'lar, proteinler ve ara metabolitler gibi belirli bileşenlerin hücresel bütününün tamamının -veya neredeyse tamamının- kapsamlı şekilde analizini sağlayan ve "omik" adı verilen gelişmiş bir teknolojiler ailesine sahibiz. Bu terminolojinin kökeni Latince bir ek olup; "topluluk, grup" anlamına gelen ve yaygın olarak kullanıldığı şekliyle "eksiksiz bir grup" manasını katan "-ome” ekinden (örneğin; biyom; belirli bir çevrede yaşayan canlıların tümü; genom; kromozomalarda yer alan genlerin tam bir seti) gelmektedir. Bu teknolojiler, hücresel homeostazi veya yapısal bütünlükteki bozuklukların moleküler düzeyde çalışılması için çok güçlü ve yeni araçlardır $[12,13]$.

Moleküler biyolojinin ve biyoinformatiğin ortaya çıkışı, bilim camiasına, dış uyaranlara karşı biyolojik tepkilerin büyük ölçeklerde analizine izin veren ve genomu temel alan yeni teknolojiler sağlamıştır. Genomik, proteomik, metabolomik ve biyoinformatik gibi yeni ortaya çıkan omik teknolojilerin kullanımı, toksik ajanlara maruz kalan bir organizmada eş zamanlı olarak hasara karşı duyarlı genleri araştırmak, toksisite kalıplarını ve mekanizmalarını tespit etmek, maruziyet ve riskin biyobelirteçlerine köken oluşturan özgün gen ifadesi profillerini belirlemek gibi amaçlarla birçok gen varyantının analizine izin vermektedir [1]. Toksikoloji, genetik ve omik teknolojileri arasındaki ilişki Şekil 3’te şematize edilmiştir.

Geleneksel toksikolojide elde edilen verilerin büyük bir kısmı histopatolojik çalışmalardan, ksenobiyotik metabolize edici enzimlerin toksikokinetik çalışmalarından, biyolojik toksisite hedeflerinin toksikodinamik çalışmalarından ve hayvan modellerinden elde edilmiştir. Bununla birlikte, en istisnai ve karmaşık verilerin, moleküler düzeyde toksikolojik mekanizmaların anlaşılması için yeni perspektifler sağlayan ve bir bütün olarak toksisitenin altında yatan fizyolojinin daha iyi tanımlanmasına yardımcı olan genomik, transkriptomik, proteomik ve metabolomik gibi yeni omik teknolojiler tarafından sağlanması beklenmektedir [1, $14]$.

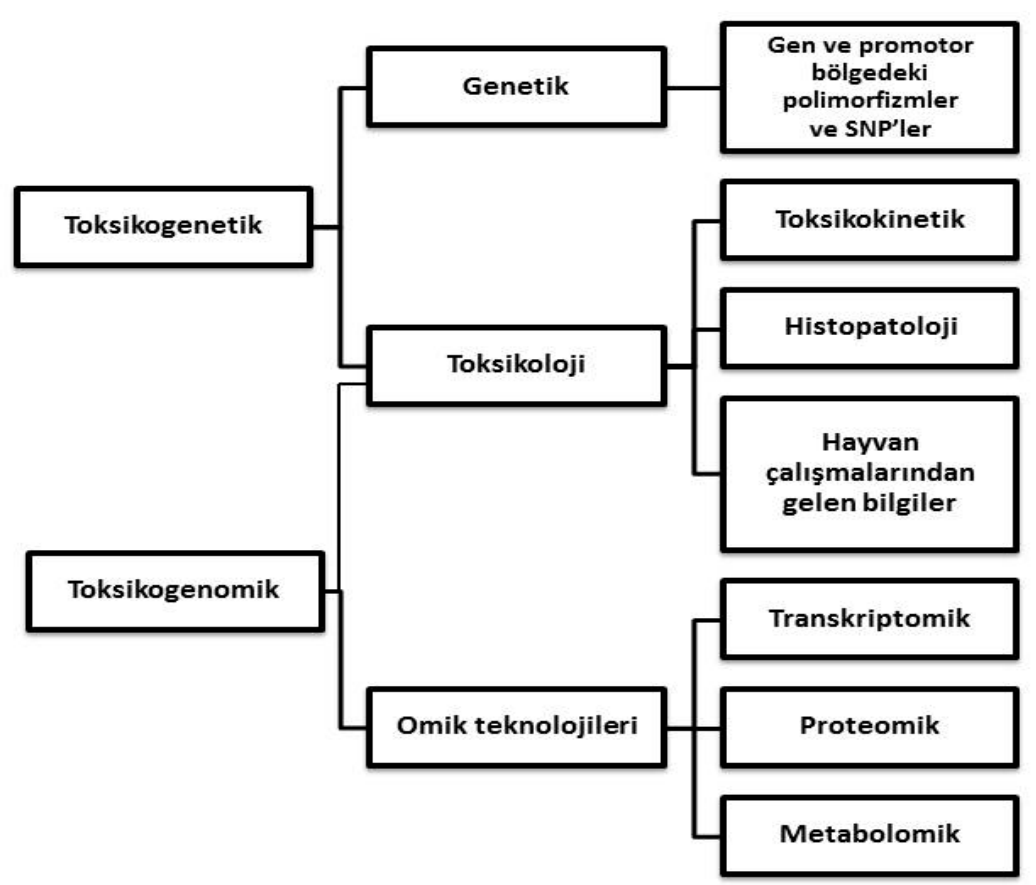

Şekil 3 Toksikoloji, genetik ve omiks teknolojileri arasıdaki ilişki [1]'den uyarlanmıştır. 
RNA, proteinler, ara metabolitler gibi hücresel molekül ailelerinin değerlendirilmesi için yeni global ölçme yöntemlerinin; “omik” teknolojilerinin yetenekleri, tek bir analizde aileye ait üyelerin tamamını ya da çoğunu karakterize etmeye dayanmaktadır. Bu araçlar sayesinde biyokimyasal yolların işlevsel aktivitelerini, bireyler ve türler arasındaki yapısal genetik farklılıkları tam olarak değerlendirmek mümkün hale gelmiştir. Bu yöntemlerin gücü, tek bir "çipte” tüm insan genlerinin ifadesinin eşzamanlı olarak ölçülmesine olanak sağlayan gen ifadesi dizilerini içermesinden kaynaklanmaktadır. Bu yöntemler, hücresel moleküllerin pek çok sınıfı için küresel bir değerlendirme potansiyeli ve hücresel sistemlerin işlevsel değerlendirmeleri için yeni yaklaşımlar sağlamaktadır. Bu yeni yöntemler sayesinde hücre ve doku hasarına karşı moleküler tepkileri ve hücrelerin işlevsel sistemlerindeki karışıklıkları anlama yolunda önemli ilerlemeler elde edilmiştir. İnsana ve diğer bazı önemli türlere ait genom dizilemesinin tamamlanmasıyla elde edilen bu bilgiler ve buna dayanan teknolojiler, hem genel hem de genetik toksikoloji alanlarını etkilemiş ve daha büyük ilerlemeler için firsat sağlamışlardır. Bu küresel metodlardan özellikle nükleik asit çipleri toksikoloji araştırmacıları tarafından büyük ilgi çekmiştir. Bu teknolojiler, ifade edilen spesifik RNAlar ya da DNA'daki polimorfizimler gibi binlerce nükleik asit sekansının eşzamanlı olarak izlenmesini mümkün kılmıştır. İfade edilen mRNAların mikroçip ile analizi, binlerce Northern Blot analizine denk gelmekte ve tüm genom boyunca bireysel genlerin ifadesini izleme imkânı sunmaktadır, ki bu da küresel gen ifade analizi veya transkriptomik olarak düşünülenbilir. Böylece araştırmacılar mikrodizi teknolojisi sayesinde, aynı anda birden fazla biyokimyasal yolu ve mekanizmayı incelemek için bir araç elde etmiş olur. Tüm bu araçların kullanımı, hücresel bileşenlerde toksikolojik değişikliklerin kapsamlı bir resmini elde etmek için önemli bir yer tutacaktır $[12,15,16]$.

Yeni genomik araçlar sayesinde, binlerce genin ifadesini etkileyen bir kimyasalın; regülasyon yolları boyunca aynı anda veya sıralı olarak analizi yapılabilir duruma gelmiştir. $\mathrm{Bu}$ genomik bilgi akışı ve ilgili teknolojiler dizisi sayesinde araştırmacılar bir ilaç, toksik ajan, toksin veya başka bir dış uyarana karşı oluşan cevapta genomik fonksiyonun saptanması için incelemeler yapabilmekte ve toksikogenomik olarak adlandırılan yeni bir araştırma alanına açılabilmişlerdir [1, 17].

\section{Toksikogenetik Ve Toksikogenomik}

Toksikoloji, toksinlere karşı oluşan cevap üzerinde etkisi olan varyasyonların genetik ve moleküler temelini derinlemesine anlamamızı sağlayan bilimsel ve teknolojik ilerlemeler vasıtasıyla son yıllarda en çok gelişen disiplinlerinden biri olmuştur. Bu bilgilerin toksikolojide uygulanması toksikogenetik ve toksikogenomik olarak da bilinmektedir. Genetik, genom dizisindeki kalıtsal farklılıklar ile biyolojik fenotip arasındaki ilişkilerin araştırılmasıdır. Genomik terimi ise, biyolojik cevaplarla ilişkili gen ifadesindeki değişikliklerin çalışılmasını tanımlamaktadır. Toksikogenomik çalışmalarda, çevresel kirleticiler, gıda katkı maddeleri ve diğer yaygın olarak kullanılan kimyasal ürünler de dahil olmak üzere kimyasal maddelere maruz kalan organizmaların genomik cevapları incelenmektedir. Toksikogenetik çalışmalarda ise genotipleme (özel genetik karakteristikler) aracılığıyla hedef proteinin izoformlarının veya ksenobiyotik ajanların birincil biyotransformasyonu ile ilişkili proteinlerin üretiminin varlığıyla toksik maddelere farklı cevaplar oluşturulması irdelenmektedir [1, 18, 19].

Toksisitenin sonlanım noktalarının ayrı ayrı ve birbirinden izole şeklide (örn. genotoksisite çalışmaları, üreme/teratoloji çalışmaları, alerjenite çalışmaları gibi) analiz etmek yerine toksisite ile ilgili tüm genlerin bir çip üzerine yerleştirilmesi yoluyla çok daha kapsamlı bir toksisite analizi sağlanabilmektedir. Moleküler biyoloji alanındaki gelişmeler, gen yapısı ve işlevi hakkında bilgilerin artışına, genetik dizi bilgisinin muazzam bir veri tabanı oluşturabilmesine ve genetik dizilerin, genetik çeşitliliğin ve küresel/işlevsel gen ifadesinin gözlenebildiği yeni teknolojilerin doğmasına sebep olmuştur. Bu gelişmeler toksikolojide yeni bir alt disiplin doğmasına olanak tanımıştır; "toksikogenomik". Toksikogenomik "genomun yapısı ve aktivitesi ile eksojen ajanların olumsuz biyolojik etkileri arasındaki ilişkinin incelenmesi” olarak tanımlanabilir. Toksikogenomik, başka bir ifadeyle, ilaçlar, çevresel olarak mevcut kirletici maddeler, gıda katkı maddeleri ve yaygın kimyasal ürünler de dahil olmak üzere kimyasal maddelerin genlerdeki etkilerinin incelenmesidir. Bu sayede, abiyotik kökenli hastalıkların gelişimi için genler ve çevre arasındaki etkileşimlerin rolünün anlaşılması mümkün olabilecektir.Bu disiplin temel olarak toksikoloji, hücre biyolojisi, genomik ve biyoinformatik alanlarındaki gelişmeler sayesinde son 20 yılda hızla gelişmiştir [1, 12, 20].

Toksikogenetik, bir bireyin (veya birey grubunun) genomunda, eksojen bir maddeye maruziyet sonucu meydana gelebilecek olumsuz etkilere karşı nispi duyarlılığını etkileyebilen kararlı ve kalıtsal değişikliklerin 
değerlendirildiği çalışma alanı olarak düşünülebilir. Diğer taraftan toksikogenomik ise, bir ksenobiyotik maruziyeti sonucu biyolojik bir sistemde başlatılan gen ifadesi değişikliklerinin analizini kapsamaktadır. Bu iki disiplin birbirine bağlıdır; biyolojik işlevi değiştiren polimorfizmler, bir toksik maddeye yanıt olarak düzenlenen genlerin spektrumunu da değiştirebilmektedir. Bu şekilde, toksikogenetik farklılıklar toksikogenomik cevaptaki varyasyonlara zemin teşkil etmektedirler. Gelecekte, genom çaplı tek nükleotid polimorfizmi (genom wide SNP) haritalamasından elde edilen gen ifade profili ve toksikogenetik çalışmalardan elde edilen toksikogenomik verilerin, toksik maddelere karşı nispi duyarlılığı belirleyen olası genlerin ve biyokimyasal yolların tanımlanmasını kolaylaştıracağı öngörülmektedir [1, 18].

Toksisite testlerinin sağladığı geleneksel bakış açısının, bazı durumlarda, toksikolojik değerlendirmenin mevcut gereksinimlerinin karşılanması husunda yeterli olmadığı düşünülmektedir. $\mathrm{Bu}$ durumun temelinde biyolojik sistemlerin karmaşık doğası ve ksenobiyotikler karşısında genel stres tepkilerinden özgün değişikliklere kadar değişen bir yelpazede ve toksisite mekanizması ile yakından ilişkili cevaplar üretebiliyor olması yer almaktadır. Önceleri bu değişkenliğin yaş, cinsiyet, kilo, sağlık durumu ve ırksal özelliklerle ilişkili olduğu düşünülmekteydi. Lakin, yapılan çalışmalar sonucunda benzer durumdaki (kilo, maruz kalınan konsantrasyon vb.) bireylerin yanıtlarında da farklılıklar olabileceği anlaşıldı. Bu sonuç, varyasyonun önemli olduğunu ve araştırmalara bireyler arası varyasyon açısından yaklaşılması gerektiğini ortaya çıkarmıştır. Kinetik ve dinamik süreçlere karışan biyomoleküllerin çoğunun, yapıları, işlevleri ve ifade derecesi, genlerin ve bu genlerin düzenlenmesinden sorumlu diğer genlerin kontrolü altındadır. Bu biyomolekülleri kodlayan genler, farklı işlev derecelerine sahip proteinler kodlayan allelomorfik varyantlara veya bazı maddeler tarafindan uyarılan veyahut bastırılan düzenleyici proteinlerin etkisine bağlı olarak ifadelerini değiştiren allelomorfik varyantlara sahiptirler. Klinik öncesi çalışmalar, insanlarda, özellikle toksisite veya immünolojik reaksiyon olarak düşük insidans gösteren ilaçların neden olduğu birçok toksisiteyi tahmin edemez. Ayrıca, hayvan modelleri uzun zaman alır, maliyetlidir ve birçok bileşiğin çalışılması için uygun değildir. Yanısıra günümüzde hayvan modellerinin, ilaçlara ve diğer ksenobiyotiklere karşı insanlarda oluşan ortaya çıkan toksisiteyi veya insanların sahip olduğu varyasyonu saptama yetenekleri bakımından da sınırlı olabileceği tespit edilmiștir. Hayvan denemelerinin tercih edilmemesinin bir diğer sebebi de "Three Rs: reduce, refine, replace (azaltmak, rafine etmek, değiştirmek)” şeklinde özetlenen etik bir yaklaşımın varlığıdır. Bu bahsedilen hususların tümü, toksisite belirtilerini daha iyi anlayabilmemiz için hücrede meydana gelen moleküler olayların genel ve eş zamanlı analizini mümkün kılmak için gerekli olan, alternatif bakış açılarını ve buna bağlı olarak yüksek verimli araçların kullanımını gündeme getirmiştir [1,21].

"Toksikoloji" ve "genomik" birlikteliğine başvuran toksikogenomik çalışmalar başlangıçta, 1999 yılında, farklı stres faktörleri ile muamelenin ardından küresel gen düzenlenmesini değerlendirmek amacıyla DNA mikrodizi çalışmaları ve klasik toksikoloji çalışmalarının kombinasyonuyla meydana gelmiştir. Vücut hücreleri belirli bir basınca veya ksenobiyotiğe maruz kaldıklarında, genlerin ifade modelini değiştirerek yanıt verirler, daha sonra genler haberci RNA'ya çevrilir. Böylece genlerde kodlanan kimyasal bilgiler proteinlere dönüştürülürek maruziyete karşı bir cevap olarak hücrenin çeşitli fonksiyonlarını geliştiren/değiştiren işlevsel proteinler sentezlenir. Belirli bir gen tarafından kodlanan bu proteinlerin üretimi, maruziyet türüne ve hücrenin ihtiyaçlarına bağlı olarak, artabilir, azaltabilir veya aynı kalabilir. [1, 22]

Yöntemin temelinde iki husus yer almaktadır, bir tarafta ksenobiyotiğin hücrelere yaptıkları; diğer tarafta hücrelerin ksenobiyotiğe yaptıkları. Daha açık anlatmak gerekirse; ksenobiyotiklerin belirli özelliklerinin hücreler üzerindeki direk toksik etki göstermeleri veya hücrenin toksik hücuma tepki vermesi için gerekli olan genlerin ifadesindeki değişimlere sebebiyet vermeleri araştırmaların bir yönünü oluşturur. Kenobiyotiklerin enzimler tarafından biyotransformasyona uğraması/uğramaması ve sonucunda organizma için olumlu veya olumsuz etkilere sebep olabilecek metabolitlerin oluşumu ise araştırmaların diğer yönünü teşkil eder.

Mekanistik ve prediktif toksikoloji, klinik çalışmalarda karşımıza çıkan olumsuz toksikolojik etkilerle ilgilinmektedir. Toksikogenomik uygulamalar, uygun tanı biyobelirteçlerinin geliştirilmesi amacıyla, bu alanlarda da çakışma göstermektedir. Toksikogenomiğin temel amaçlarından biri gen-çevre etkileşimi ile insanda hastalığa yatkınlık arasındaki ilişkiyi anlamaktır. Bunu yaparken de zarara yatkınlıktan sorumlu olabilecek genleri ve maruziyet biyobelirteçlerini oluşturan ifade profillerini, klinik belirtiler ortaya çıkmadan belirleme çalışılmaktadır. Bir hastalığın gelişimini zamanından önce tanımlayabilen erken etki biyobelirteçlerini tanımlamak ve toksisitenin moleküler mekanizmalarını açığa çıkarmayı hedeflemektedir [1]. 
Toksikogenomik yönden, kimyasal ürünlere maruz kalan biyolojik sistemlerin gen ifade profilleri yapılır. Bu gen ifadelerinin veri analizleri, hücrelerin durumu ile kimyasal ve çevresel uyaranlara verdiği yanıtlar hakkında önemli bilgiler sağlayabilir. Bu bilgiler ise ksenobiyotik ajanların -özellikle yeni kimyasal maddelerinpotansiyel toksisitesini tahmin etmek için ve toksisite mekanizmalarının aydınlatılması amacıyla kullanılabilmektedir [1, 19].

Kimyasal ürünlere maruz kalma biyolojisinin genel bir değerlendirmesi, toksik ajanların etki mekanizmalarının daha iyi anlaşılmasına yardımcı olabilme ihtimali toksikogenomiğin ana odaklarından birini oluşturmaktadır. Toksikogenomik bunun için, belirli bir toksik cevabı idare etmeyi ve hatta uyarmayı öğrenmek amacıyla, bilinen prototip bileşiklerin (biobelirteç genlere dayanarak) gen ifadesindeki "işaretler ve parmak izleri”ndeki değişimleri, daha sonra bilinmeyen bileşiklerin etki mekanizmasını daha iyi anlamak amacıyla tanımlamaya çalışmaktadır. Bu işaretleri kullanmanın ardındaki amaç, bir yandan, toksik yanıtın altında yatan biyolojiyi daha iyi anlamak diğer yandan, yeni bileşiklerin test edilmesi için stratejiler geliştirerek gen ifadesi profilleri temelinde muhtemel toksisiteyi belirlemektir.

İnsan genomunu oluşturan üç milyar baz DNA'nın sadece yaklaşık \% 0,1'i bireyler arasında farklılık gösterir. Bununla birlikte, genomun bu küçük kısmında kodlanan bilgi biyolojik yapı üzerinde büyük etkilere sahip olabilir. $\mathrm{Bu}$ dizi farklılıklarının sebep olduğu en dramatik örnekleri prematüre ölümlere veya ağır engelliliğe sebep olabilen dizi değişimleridir. Yanı sıra, daha önce genetik hastalık olarak kabul edilmeyen obezite, kanser ve kardiyovasküler hastalıklar gibi klinik durumlara karşı yatkınlığın da bu dizi farklılıklarından kaynaklandığına dair kanıtlar artmaktadır. Genetik yapı aynı zamanda ksenobiyotiklerin tanınmasını ve oluşacak yanıtları da etkilemekte ve bunun sonucunda, uyarılmış yan etkilere karşı nispi yatkınlığa da etki etmektedir. İlaçlara ve çevresel kimyasallara verilen cevap genotip ile çeşitlenmektedir. Bazı hastalar bazı ilaçlara iyi tepki verirken, diğerleri o ilaçtan fayda göremez, hatta olumsuz etkilenebilirler. Bireyler ayrıca alerjenler gibi çevresel etkenlere karşı da farklı tepkiler sergilerler. İnsan genomunun dizisi ve polimorfizmlerin geniş çapta tanımlanması, muhtemel toksik maddelere karşı ortaya çıkan yanıtların bireysel farklılıklarının genetik temelini anlama fırsatları sağlamıştır. Toksikogenetik olarak bilinen çalışma alanı böylelikle ortaya çıkmıştır [23].

Gen dizisi varyasyonunun (polimorfizm) değerlendirilmesi için kullanılan yöntemler sayesinde, genetik varyantların toksik maddelere karşı verilen yanıtlar üzerindeki etkilerinin sistematik bir değerlendirmesi mümkün olmuştur. Kimyasal maruziyetlerden kaynaklanan yan etkilere karşı hassasiyeti etkileyen genetik varyantların örnekleri uzun zamandır bilinmektedir. Bu genetik çeşitliliğin hastalık ve kimyasal maddelere karşı duyarlılık ile olan ilişkisinin anlaşılması, bireysel sağlık-risk değerlendirmesi ve laboratuvar modellerindeki bulgulardan yola çıkılarak insandakilerin tahminine kadar birçok şeyi büyük ölçüde kolaylaştıracaktır. Şu anda mevcut olan metodlar genetik toksikoloji alanına uygulandıkça, iki önemli gelişmeye yol açabilir: (i) Belirli ajanlardan kaynaklanan toksisiteye duyarlılıktan sorumlu olan polimorfizmlerin tanımlanması ve (ii) Belirli hastalıkların kimyasal uyarımlı genetik değişiklerle ilişkisinin belirlenmesi. Ayrıca, bu genetik varyasyonun, toksik maruziyete yatkınlıktaki değişim için başlıca nedenlerden biri veya belki de en önemli nedeni olabileceği beklenmektedir. $\mathrm{Bu}$ görüş, genetik varyantlarla ilişkili spontan patolojilerin (hastalıklar) üstel olarak büyüyen listesi tarafından da desteklenmektedir, çünkü bu tür varyantların çoğunun hem spontan hem de kimyasal olarak indüklenen patolojileri etkilemesi muhtemeldir [12, 24].

İnsan genomundaki varyasyonun çoğu tek nükleotid poliforfizmlerinden (SNP) oluşmaktadır. SNP'ler ortalama her 1000-2000 bp'de bir görülürler. \%99'undan fazlası biyolojik olarak sessiz haldedir; geri kalanın etkileri ve biyolojik önemi genom içindeki pozisyonlarına göre değişir. Polimorfizimler biyolojik işlevleri çeşitli yollarla etkileyebilir. Polimorfizmlerin biyokimyasal sonuçlarını listelemek önemli olsa da SNP haritalarının en heyecan verici uygulaması, kalıtsal özellikler ile ilişkili olan allellerin tanımlanmasıdır. Bir gen bölgesinin sınırlarında yer alan hastalık ile ilişkili bir SNP, hastalığın mekanik temeli hakkında bilgi sağlayabilirken, hastalığa yatkınlık sağlayan genetik allel olan bir SNP, bağlantı dengesizliği sayesinde yatkın bireyleri tanımlamak için kullanılabilir. SNP haritalaması, kalıtsal özellikler ile doğrulanabilir bir şekilde ilişkilendirilen polimorfizmleri tanımlamaktır. Dolayısıyla bireyin toksik maddelere karşı nispi yatkınlığını veya direncini etkileyen kalıtsal özellikler de bu çalışmaların kapsamına girmektedir [23].

Bir genin kodlama bölgesinde yer alan SNP'ler, bir amino asiti değişmiş ya da parçalanmış olan bir protein sentezine sebep olarak proteinin etkinliğinde, yerleşiminde veya kararlılığında bir değişikliğe neden olabilmektedirler. Translasyonel okuma çerçevelerindeki değişiklikleri indükleyen polimorfizmler ise, amino asit dizilimindeki değişiklikler sonucu farklı proteinlerin üretimi ve dolayısıyla proteinin etkinliğinin kaybına yol 
açabilir. Bir genin düzenleyici bölgelerindeki nükleotid değişiklikleri, proteinlerin ifade edileciği zamanı ve miktarı etkileyerek proteinlerin işlevsel bütünlüğü üzerinde de önemli bir etkiye sahip olabilmektedir. Promotor bölgelerindeki polimorfizmler, bir proteinin düzenlenmesini ve ifade seviyesini değiştirebilirken, intron-ekson bölgelerine yakın olan polimorfizmler, mRNA'nın işlenmesinde değişikliklere neden olabilmektedirler. [1, 25]

Genetik çeşitlilik, bireylerin kimyasallara maruz kalmaya karşı nasıl tepki gösterdikleri konusunda da önemli bir faktör olarak kabul edilmektedir. $\mathrm{Bu}$ nedenle, metabolize edici enzimlerin etkinliğinde veya ifadesinde varyasyonların olması normaldir ve bu da sonunda ksenobiyotik metabolizmasında bir değişikliğe yol açabilecektir [1, 24].

İlaç tedavisine yanıt olarak ortaya çıkan farklılıklar genellikle yabancı bir bileşiğin farmakokinetik parametrelerini etkileyen proteinleri kodlayan genlerdeki polimorfizmlere bağlıdır. Örneğin, ksenobiyotik metabolize edici enzimlerde değişikliklere neden olan polimorfizmler, diazepam, omeprazol ve karbemazepin dahil olmak üzere birçok ilaca verilen cevabı etkileyebilir. Belirli bir metabolize edici enzimdeki bir kusur nedeniyle bir ilacın inaktivasyonunun başarısız olması, klerenste gecikmeye ve dolayısıyla istenmeyen yan etkilerin ortaya çıkmasına neden olabilir [23].

İlaçların ve diğer yabancı kimyasalların ilk metabolizasyonu, ağırlıklı olarak, sitokrom P450 (CYP) enzim ailesi tarafından gerçekleştirilir. Varolan 63 insan CYP geninin çoğunun polimorfik olması, ksenobiyotiklere verilen yanıtlarda bireyler arası farklılıklar için bir dayanak noktası oluşturmaktadır. Bu aileden CYP2D6 genindeki polimorfizmler kapsamlı olarak incelenmiştir. Bu gen tarafından kodlanan enzim, tüm ilaçların neredeyse \% 25'ini ve keza çevresel kimyasalların da buna yakın bir oranını metabolize etmektedir. Bu genin geçersiz (null) allelerini taşıyan "yetersiz metabolize edici (poor-metabolizer)" fenotipte bireyler olduğu gibi gen amplifikasyonu sonucu oluşan 13 kopya gene bağlı olarak -neredeyse 13 kat- fazla enzim sentezleyebilen "aşırı metabolize edici (ultra-high metabolizer)" fenotipler de literatürde yer almaktadır [23, 26].

Diğer gen ailelerindeki polimorfizmler de yabancı bileşiklere karşı oluşturulanan bireysel cevabı etkileyebilmektedirler. Kimyasalların çoğu "faz I" (işlevselleştirme) ve "faz II" (konjugasyon) olaylarını içeren biyokimyasal bir yolla metabolize edilir. CYP enzimleri faz-I metabolizmasında yer almaktadırlar. Glutatiyon Stransferazlar gibi faz-II enzimlerinin aktivasyonundaki değişiklikler de ilaçlara ve çevresel kimyasallara karşı olan cevabı etkileyebilir. Aralarında ilaç taşıyıcılar, plazma zarında bulunan proteinler, nükleer reseptörler ve iyon kanalları gibi özel görevleri olan protein gruplarının yeraldığı diğer protein ailelerindeki polimorfizmlerin de ksenobiyotiklere olan cevabı etkilemesinin muhtemel olduğu düşünülmektedir [23, 27].

Yeni bir ilacın geliştirilmesi, umut verici bir çalışma olsa da bunu bir felakete dönüştürebilecek olumsuz sonuçlardan dolayı başarısızlığa uğrayabilecek karmaşık, maliyetli ve uzun süreli bir araştırma sürecini de bünyesinde barındırır. İndüklenen toksisitenin erken ve güvenilir tahmini, farmasötik madde geliştirmede ana zorluklardan birini temsil eder. Umut verici bir moleküle dair yürütülen çalışmaların durdurulmasının sebebi \% 44'e yakın oranda toksik etkilerden dolayı olmaktadır. Bu duruma da sebebiyet $\% 75$ oranında faz I, faz II ve faz III aşamalarındaki başarısızlık olarak değerlendirilmektedir. Sonuç olarak, toksik etkilerin moleküler düzeyde teşhisi, en umut verici adayların değerlendirilmesi için daha uygun bir araç olarak düşünülmektedir. Bu sayede mevzubahis bileşiklerin daha verimli ve makul bir maliyetle geliştirilebilecekleri öngörülmektedir. Umut verici moleküllerin toksikolojik etkilerinin değerlendirilmesindeki eksiklik, zaman ilerledikçe toksikogenomik yaklaşımlar sayesinde giderilebilir duruma gelmiştir. $\mathrm{Bu}$ yaklaşımların diferansiyel gen ifadesinin uygulanmasına dayanarak, yeni tedavi edici ajanların geliştirilmesini sağlayabilecek güce sahip olduğu düşünülmektedir. Toksikogenomik yaklaşımların ve çalışmaların tercih edilmesinin sebebepleri arasında bu tekniklerin, yeni moleküllere veya ilaçlara karşı gelişen olumsuz reaksiyonları daha erken, daha hızlı ve kesin olarak tanımlayabilme ve değerlendirebilme konusunda sağladığı avantajlar da yer almaktadır. Bahsedilen avantajlar da bu alanda yapılan uygulamaların, molekül seçimi konusunda güvenlik ve etkililik temeline dayanan kararlar alınmasına izin verebilmektedir [12].

Yüksek verimli genomik tekniklere uygun olarak, yüksek verimli proteomik ve metabolomik teknikler, sırasıyla, küresel protein ifadesinin haritalanmasına ve hücresel küçük moleküllerin saptanmasında katkı sağlamaktadırlar. Toksikogenomik, mRNA'nın küresel analizini ifade etse de tanımı zamanla genişlemiştir. Şu anda, kimyasalların organizmalar üzerindeki etkilerini incelemek için mRNA'ların (transkriptomik), proteinlerin (proteomiklerin) ve metabolitlerin (metabolomik) küresel analizini içeren kavramsal olarak geniş bir terim haline gelmiştir [3]. 
Toksikogenomik gelişmeler de sistemler toksikolojisi kavramının gelişmesine öncü olmuştur. Sistemler toksikolojisi terimi, sistemler biyolojisi kavramından sonra Waters ve Fostel [28] tarafindan öne sürülmüştür. Sistemler Biyolojisi; bir doku, hücre ve/veya organizma gibi biyolojik bir sistemin tümünün genomikten, metabolomiğe doğru tüm araçlar kullanılarak incelenmesi anlamına gelmektedir Küresel genomik verilerin bilgisayarla bütünleştirilip modellenebildiği varsayımına dayanan sistemler toksikolojisinde, yaşayan bir sistemdeki tüm toksikolojik etkileşimlerin tanımlanması amaçlanmaktadır. Dolayısıyla, sistemler toksikolojisi, geniş bir biyolojik moleküller ve makromoleküller ağının etkileşimlerinin analizini ve bunların bir kimyasal maddeye maruz kaldıktan sonraki karmaşalarını içermektedir [15, 28, 29].

Bilindiği üzere, hayvan toksisite testleri mevcut toksisite verilerinin çoğunun kaynağı olarak toksikolojide bilgi birikimimizi geliştirmeye yardımcı olmuştur. Bununla birlikte, deneysel hayvan toksikolojisinin uzun tarihi ve sağlamış olduğu faydalarına rağmen, hiçbir hayvansal modelin, bir kimyasalın insanlardaki kaderini ve etkisini tahmin etmede mükemmel olmadığı da bilinmektedir. Bu sebeple, deney sonuçlarının hayvandan insana uyarlanması kuşkulu ve çetrefilli olabilmektedir. Hatta, insanlarda yapılan çalışmalar bile tüm insanlar düşünüldüğünde mükemmel modeller değildirler. Örneğin, bir bileşiğin yetişkinlerdeki toksisitesi ve metabolik akıbeti, bebeklerde aynı şeyi tahmin etmede genellikle yararlı olmayabilir. Aynı şekilde, bireyler arası değişkenliğe bağlı olarak, bir bileşiğin bir insan alt popülasyonundaki toksisitesi ve metabolik akıbeti, tüm insan popülasyonu için aynı şekilde yansıtıcı olmayabilir. Örneğin, Faz III klinik denemelerini geçen ilaçların, klinik çalışmalara katılan gönüllüler baz alınarak beklenen kaderinden farklı olarak, bazı insan alt popülasyonlarında toksisite gösterebileceği bilinmektedir [3].

Epigenetik terimi, genetik materyalde yer alan bilginin (sekansın) değişmeden; kromatinin yeniden modellenmesini sağlayan özgün modifikasyonlar vasıtasıyla hücrenin gelişimi ve çoğalması sırasındaki gen ifadesindeki değişiklikleri kapsamaktadır. Bu olaylar, histon ve DNA'nın kimyasal varyasyonları aracılığıyla gerçekleşmektedir. Ana modifikasyonlar arasında DNA metilasyonu, sitozinlerin kovalent modifikasyonu ve histonların transdüksiyon sonrası modifikasyonları (metilasyon, asetilasyon, ve fosforilasyon) yer alır. Epigenetik değişiklikler bireylere, çeşitli hastalıkların gelişiminde yatkınlık kazandırabilir. Örneğin insanlarda ortaya çıkan kanserlerin bir kısmında "normal” DNA metilasyonu modellerinden sapmalar görülmektedir. Ayrıca, bireyler arasındaki epigenetik farklılıkların ksenobiyotiklere karşı hassasiyeti ve bunlarla ilişkili hastalık riskini de etkileyebileceği düşünülmektedir. Bu bağlamda yapılan toksikoepigenomik çalışmalarda, ilaçlara veya çevresel toksik maddelere maruz kalmanın bir sonucu olarak genom çapında epigenetik değişiklikler incelenmektedir [1, 3].

Toksikogenomiği, genomik zemininde yapısal ve fonksiyonel kategoriler altında sınıflandırabiliriz. Yapısal genomik, tüm genomun fiziksel karakterizasyonu ile ilgilenir. Başka bir deyişle, DNA molekülünün nükleotidlerinin sayısını, düzenini ve sırasını çözmeyi amaçlamaktadır. Bu süreçte genotipleme yapılır. Bir organizmanın DNA sekansındaki bireysel varyasyonların analizi genotipleme olarak bilinir. Laboratuar tekniklerini uygulayarak, bir organizmanın veya genotipin genetik bilgisinin bulunması, böylece her bir genetik varyanta karşılık gelen alellerin saptanması sağlanır. Bu işlem için şu anda mevcut olan yöntemlerden bazıları şunlardır: geleneksel veya real-time PCR, DNA dizilemesi, ASO probları ve DNA mikrodizinlerinde hibridizasyon veya mikrosferler [1].

Öte yandan, fonksiyonel genomik, genom bilgisini ve dizilemeyi kullanarak genlerin işlevini değerlendirmek için deneysel odakların geliştirmesi ve uygulanması olarak tanımlanabilir. Toksikoloji bağlamında ise fonksiyonel toksikogenomik olarak kabul görmektedir. Başka bir deyişle, bir organizmada bulunan genlerin ve proteinlerin biyolojik aktivitelerinin toksik bir ajanın etkilerine verdikleri cevabın çalışılmasına karşılık gelmektedir. Fonksiyonel genomik, doğrudan fenotipi ölçer. Sonuç olarak bu çalışmalar, spesifik genlerin veya gen ağlarının, bunların varyantları (polimorfizmler) ve ürünleri ile bir ksenobiyotiğe karşı gelişen hücresel cevabın varyasyonu arasında doğrudan bir bağlantı kurmayı hedefler. [1]. Fonksiyonel genomik uygulamaları Şekil 4.' te gösterilmiştir.

\section{Transkriptomik, Proteomik Ve Metabolomik}

Çok sayıda organize genin ifade düzeyindeki değişiklikler biyolojik süreçleri, ayrıca özel biyolojik işlevleri, biyokimyasal yolları ve ağları düzenlediğinden işlevsel genomiğe mRNA sentezi seviyesinde yaklaşmak mümkündür. Toksik ajanlar vücuda girdiğinde, bir veya birkaç genin ifadesinde değişikliklere 
akabinde de hücrelerin, dokuların, organların normal çalışması için hayati öneme sahip olan ilgili biyolojik işlevlerin, ağların ve yoların sekteye uğramasına sebep olabilir. Bu nedenle, bu genlerin ifade düzeylerinde meydana gelen değişikliklerin, toksisitenin bir yansıması olabileceği düşünülmüştür. Toksik ajanlara maruziyet sonucunda hedef organların gen ekspresyonundaki değişikliklerin belirlenmesi, toksik sonlanım noktaların klinik öncesi tanı alması için bir firsat sağlayarak olumsuz etkilerin önlenmesi konusunda etkili müdahale stratejilerinin uygulanmasına katkı sunabilir. [1, 15, 30].

Transkriptom, DNA mikrodizi veya DNA mikroplate analizleri kullanılarak gen ifadesinin küresel profili ile ölçülmektedir. Böylece, binlerce genin eş zamanlı analizi elde edilmiş olur. Bu teknoloji sayesinde, bir hücre, doku veya organ içindeki karmaşık düzenleyici mekanizmaların tanımlanması mümkündür. Böylelikle organizmanın, farmasötikler, gıdalar veya toksik maddeler dahil olmak üzere ksenobiyotiklere karşı nasıl tepki verdiği konusunda küresel bir bakış açısı sağlanabilmektedir. Elde edilen veriler, maruziyet sonrası veya çevresel bir ajanın sebep olduğu toksisite mekanizmasında önemli moleküllere karşılık veren, tanımlayan ve biyolojik duyarlılığı ölçen biyobelirteçler sağlayan hücresel gen ağları hakkında bilgiye ulaşmamızı sağlamaktadır. Ayrıca, bu bilgilerin; çevresel kimyasallar tarafından bozulan biyokimyasal ve moleküler işlevlerin lokalizasyonunu sağlayarak hasarı/hastalığı azaltmanın veya önlemenin yollarını belirlememize de olanak sağlayacağ düşünülmektedir. Her ne kadar çalışmalarda sıklıkla tercih edilen doku olan periferik insan kanında, transkriptin dinamik olduğu, stres, egzersiz, diyet ve yaşam tarzı gibi çevresel faktörlere yanıt olarak kendisini modüle ettiği bilinmekle beraber, bu moleküler tekniğin sağladığı bir avantaj da transkriptlerin ifade seviyelerindeki modülasyonların incelenmesi yoluyla toksik etkilerden haberdar olmamıza izin vermesidir. [1, 15, 30].

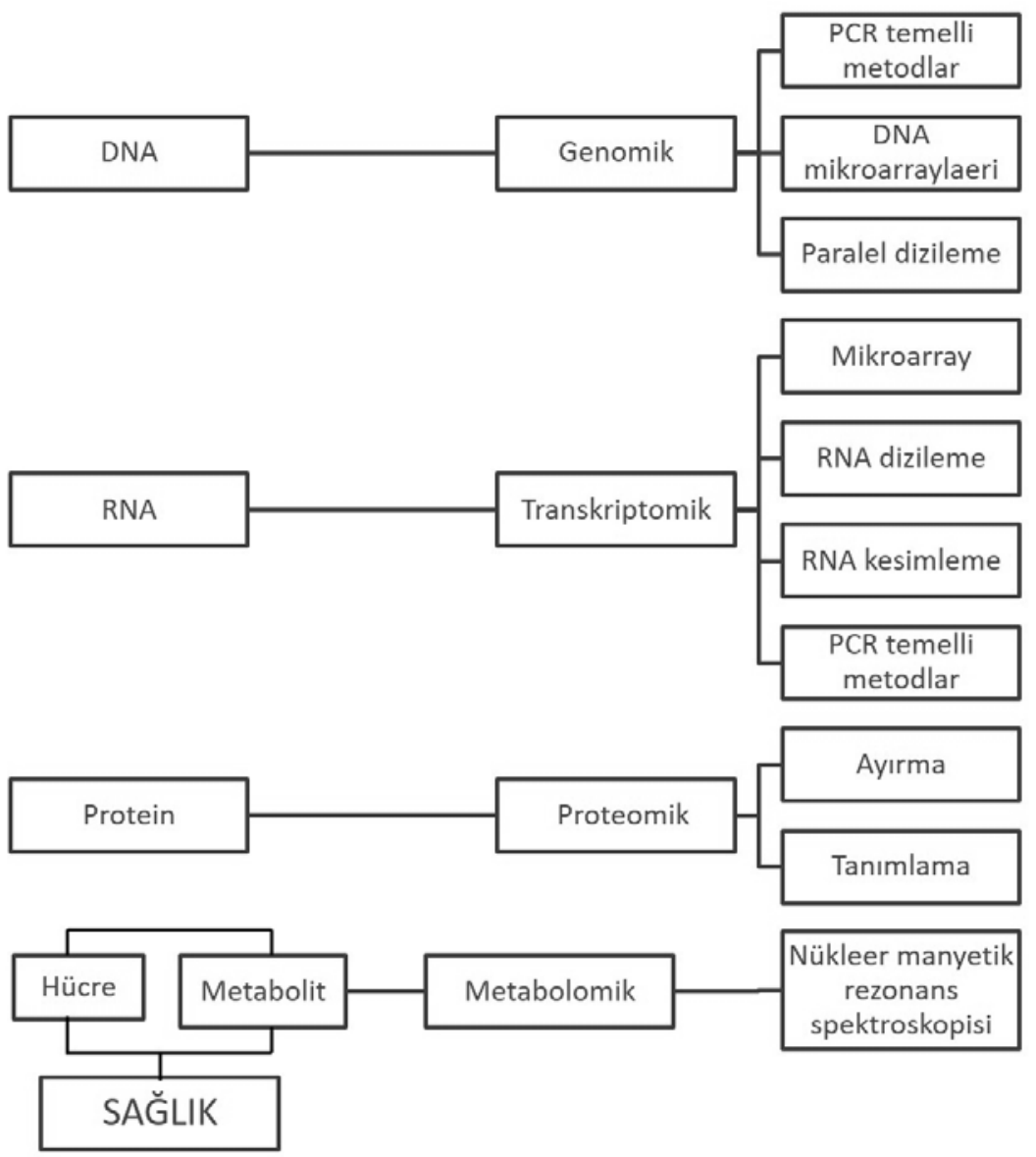

Şekil 4 Fonksiyonel genomik uygulamaları [1]'dan uyarlanmıştır. 
Proteinler tüm biyolojik süreçlerde nihai aracıdırlar. Bu nedenle, transkriptoma kıyasla proteomun moleküler ve hücresel süreci daha iyi yansıtabileceği düşünülmektedir. Proteom, belirli bir zamanda ve belirlenen zaman ve ortam koşullarında bir genom tarafından ifade edilen proteinlerin toplamı olarak tanımlanır. Bir organizmadaki her hücre aynı genomu içerir, ancak farklı hücre tipleri birkaç bin farklı protein sentezler ve her bir protein belirli bir mikroçevreye cevap olarak çok sayıda modifikasyona uğrayabilir. Proteomik, proteomların çalışılmasından sorumlu olan fonksiyonel genomikin bir parçası olarak tanımlanır ve protein ekspresyonu seviyelerindeki nicel değişikliklerin ve hücrelerdeki proteinlerin translasyon sonrası modifikasyonlarının genel analizini hesaplar. Proteomik analiz çalışmaları sonucunda, varolan proteinlerin tanımlanması, proteinlerin miktarlarının belirlenmesi, proteinlerin lokalizasyonu, 3 boyutlu yapıları ve translasyon sonrası modifikasyonları ile protein-protein etkileşimleri de dahil olmak üzere hücre içi mikroçevre hakkında önemli bilgiler elde edilmektedir. Bu sayede, proteomik araştırmalar, biyolojik sistemlerin davranışları hakkındaki bilgimizi artırmaya katkıda bulunarak, toksisiteyle ilişkili olabilecek protein koleksiyonlarının kontrolü yoluyla biyokimyasal değişikliklerin tanımlanmasını mümkün kılabilmektedir. Yöntemin sağladığ avantajların yanı sıra, proteomik teknikler kullanılarak genom tarafından kodlanan toplam proteinlerin üretiminin analizi, proteinlerin özellikleri, konumu ve bolluğundaki farkl1lıklar nedeniyle büyük çapta uygulamalar için karmaşık ve daha az duyarlı olarak değerlendirilmektedir $[1,15,30]$.

Metabolom, hücre içinde bir popülasyona sahip ve gen ifadesinin son seviyesi ile ilgisi olan substratların, metabolitlerin ve diğer küçük moleküllerin toplamı olarak tanımlanabilir. Metabolomik, bu küçük moleküllerin $(<1 \mathrm{kDa})$ yapısının ve dağılımının küresel ve nesnel bir çalışması olarak tanımlanır. Metabolomik, hücresel metabolizmanın nihai ürünlerinin, biyolojik sıvılardaki, dokulardaki, organlardaki veya organizmadaki endojen ve eksojen substratların metabolitlerinin tam ölçümü ile alakadar olmaktadır. Metabolitleri tanımlamak için farklı nicel analitik yöntemler geliştirilmiştir. Büyük ölçüde, nükleer manyetik rezonans spektroskopisi ve kütle spektrometresi uygulanmaktadır. Nükleer manyetik rezonans spektrumlarında tespit edilen sinyaller, metabolitlerin yapısı hakkında bilgi verirken, kütle spektrometresinden elde edilen $\mathrm{m} / \mathrm{z}$ fragmanları, moleküler ağırlıklar ile ilişkilidir. Bu teknikler sonucunda, peptidler, amino asitler, şekerler, lipitler ve nihai bozunma ürünleri gibi küçük endojen moleküller hakkında yapısal ve nicel bilgi elde edilebilir. Metabolomiğin, numunelerin kolay hazırlanması, verilerin elde edilmesi ve preklinik (hayvan) ve klinik çalışmalarda minimal invaziv prosedürlerle toplanan biyolojik sıvıların kullanımının kolay olması nedeniyle diğer omik teknolojilere kıyasla daha tercih edilebilir olduğu düşünülmektedir [1, 15, 20, 31].

Test dışı yaklaşımlar, mevcut verilerin (işlemsel/bilgisayarlı toksikoloji çalışmalarından elde edilen) kullanılarak geliştirildiği ve doğrudan laboratuvar deneyleri olmayan öngörü modellerin kullanıldığı çalışmaları kapsamaktadır. Bilinen bir toksik madde ile yapısal benzerliğine dayanarak bilinmeyen bir bileşiğin toksikliğinin hesaplanması -yapı-aktivite ilişkisi (structure-activity relationship: SAR) (in silico), biyolojik çalışmalarda bilgisayarların kullanıldığı ilk uygulamalar arasında yer almaktadır. Hesaplamalı toksikoloji çalışmaları sonucunda iyi bir öngörü modeli elde etmek, toksikolojik bir son nokta (reseptör bağlanması, mutajenite veya genotoksisite deneyleri gibi) ile ilişkili olan tüm farklı kimyasal sınıfların özelliklerinin bütün yelpazesinin ideal olarak yer aldığı iyi bir çalışma veri seti eldesine bağlıdır [3].

\section{Sonuç}

Birçok ilaçtan kaynaklanan yan etkilere karşı duyarlılıkların, ilaç metabolizması yollarının modifikasyonundan (örneğin, terfenidin, isoniazid) kaynaklandığı bilinmektedir. Bu sebeple ilaç metabolizması için bilinen insan enzimlerinin varyantlarını ihtiva eden gen çipleri böyle bireyleri tanımlamak için geliştirilen teknolojilerdir. $\mathrm{Bu}$ teknolojinin daha kullanılabilir hale gelmesiyle beraber, bireye ait metabolik enzim genotipinin, tıbbi kayıtların rutin bir parçası haline gelmesi ve böylece uygun ilaçları seçerek dozları bireysel olarak ayarlayabilmenin mümkün hale geleceği ön görülmektedir [12, 17, 32].

Günümüzde insan genlerinin ve hücresel makromoleküllerin normal veya polimorfik formlarını içeren "insanlaştırılmış" modellerini laboratuvar ortamında yapmak mümkün durumdadır. İlaç ve toksik etkileşimler için önemli olan insan hedefleri belirlendiği ve karakterize edildiği için, bu etkileşimlerin hayvanlarda, hücrelerde ve dokularda incelenmesine olanak tanıyan benzer laboratuvar modellerinin kullanımı da söz konusu 
olabilir. Bu şekilde yapılan çalışmalara orak hücre hastalığı hayvan modelleri ve insan sitokromu P450 enzimlerini ifade etmek üzere tasarlanmış hücre dizileri örnek olarak verilebilir [12].

Son gelişmeler toksikologların multidisipliner bir genetik anlayışını, hücresel sinyal iletimi ve kontrolünü ve geleneksel patolojiyi bilmesini gerekli kılmıştır. Bu disiplinlerin füzyonu ile toksikoloji alanında önemli ve faydalı bir dönüşümün olması beklenmektedir. Toksikolojinin ve genetik toksikolojinin geleceği, bu disiplinlerin birleşmesinde ve kimyasalların hücresel değişiklikler üzerindeki etkilerini daha bütünsel bir şekilde anlamak için genetik tekniklerin ve biyobelirteçlerin doğru bir şekilde uygulanmasında yattığı ifade edilmektedir.

Toksikogenetik ve toksikogenomik, ksenobiyotiklere duyarlılı̆̆ın saptanabileceği prediktif toksikolojinin gelişimine katkı sunmaktadır. Böylelikle bu alanlar sadece daha güvenli ve etkili ilaçların geliştirilmesini değil aynı zamanda bireyin yiyeceklerinde ve iş ortamında bulunan kimyasalların risk değerlendirmesi bağlamında da sağlık üzerindeki çevresel etkileri tahmin etme konusunda imkân tanımaktadır [1].

Çevre, insan yaşamını çevreleyen her şeydir: Soluduğumuz hava, içtiğimiz su ve tükettiğimiz besinler. $\mathrm{Bu}$ çevre, on binlerce sentetik ve doğal kimyasal ürün, mikroorganizmalar, radyasyon, pestisitler, endüstriyel yan ürünler, virüsler ve bireylerin günlük yaşamlarında etkileşimde bulundukları fiziksel faktörleri barındırır. İnsanlar ve çevreleri arasındaki etkileşimler karmaşıktır. Bazı senaryolarda bu etkileşimler hastalık, sakatlık ve ölümle sonuçlanır. Hastalıkların nedenlerinin belirlenmesi, önlenmesinde ilk adımdır. Çevredeki toksik maddelerin etkileri hakkındaki bilgilerimiz sınırlıdır. Hangi bileşiklerin insanlarda hastalıklara sebep olabileceği ya da hastalıklara karşı yatkınlık gelişimine katkıda bulunabileceğini belirlemek çok büyük bir sorundur. Kentsel alanlarda yaşayan insanlar, bazıları insan için zehirli olan çevresel kirleticilere (arsenik, polisiklik aromatik hidrokarbonlar, nitrozaminler, ağır metaller vs) maruz kalmaktadır. Son zamanlarda, "ekotoksikogenomik" terimi ekotoksikolojik araştırmalarda toksikogenomik yöntemlerin kuulanımı olarak ifade edilebilir. Ekotoksikogenomik, ekolojik risk değerlendirmesinde fayda sağlayan ve çevresel toksisite hakkında bilgi vermek üzere ekolojik organizmalardaki tüm gen veya protein ifadesinin incelenmesi olarak düşünülebilir [1, 33].

Bir kimyasal maddenin çevreye salınımı hakkında pratik kararlar verebilmek için bu maddenin toksisitesi ile ilgili bilimsel verilerin değerlendirildiği süreç, risk değerlendirilmesi olarak adlandırılır. Toksikogenomik çalışmalar, bu bilginin geliştirilmesi için kapıyı açar, böylece insan sağlığı açısından riskleri tanımlamak maksadıyla öngörü modellerinin oluşturulmasını sağlayarak kimyasal risklerin çoklu seviyelerde (toksikokinetik ve toksikodinamikler) değerlendirmesine katkı sağlar. Bu tip çalışmaların zamanla etik açıdan çatışmalara yol açan laboratuvar hayvanlarının kullanımının yerini alacağı düşünülmektedir. Bu alana dair bir diğer beklenti de moleküler parmak izinin ve tipik etki mekanizmalarının karakterizasyonu yoluyla, kimyasal ürünlerin ve ürün karışımlarının sınıflandırılmasının uygulanabilir hale gelmesidir. Bu gelişmelerin, çevre yönetimi ve endüstriyel güvenlik politikalarının tasarımına da katkı sunması muhtemeldir [1, 34].

Günümüzde kullanılan 100.000'e yakın kimyasal madde mevcuttur ve bunların sadece küçük bir kısmının toksikolojik değerlendirmesi yapılmış durumdadır. Dolayısıyla, bilim adamları bu maddeleri taramak ve etki tespiti yapmak için alternatif yaklaşımlara ihtiyaç duymaktadırlar. Son gelişmeler ve yapılan çalışmalar değerlendirildiğinde toksikolojinin, kendisini hızla daha bütünsel bir bilimsel disipline dönüştüreceği ve çalışmalarda ivme kazanacağı ön görülmektedir [3, 35].

\section{Kaynakça}

1. Ancizar-Aristizábal, F., et al., Approaches and Perspectives to Toxicogenetics and Toxicogenomics. Revista de la Facultad de Medicina, 62, 4, 605-615,2014 
2. Wang, Y., et al., Techniques for Investigating Molecular Toxicology of Nanomaterials. Journal of Biomedical Nanotechnology, 12, 6, 1115-1135,2016

3. Choudhuri, S., et al., From Classical Toxicology to Tox21: Some Critical Conceptual and Technological Advances in the Molecular Understanding of the Toxic Response Beginning from the Last Quarter of the 20th Century. Toxicological Sciences, 161, 1, 5-22,2018

4. Vural, N., Toksikoloji. 2005.

5. Güley, M. and N. Vural, Toksikoloji. 1978, Ankara: Ankara Eczacılık Fakültesi. 326.

6. Özdemir, F., Z. Kayaaltı, and D. Kaya-Akyüzlü, Ksenobiyotiklerin DNA Üzerindeki Toksik Etkileri Ve Toksikogenetik. 2015,Parkinson, A. and B.W. Ogilvie, Biotransformation of Xenobiotics. 2001, McGraw-Hill New York.

7. Council, N.R., Applications of Toxicogenomic Technologies to Predictive Toxicology and Risk Assessment. 2007: National Academies Press.

8. Marshall, E., Toxicology Goes Molecular. Science, 259, 5100, 1394-1398,1993

9. Bouvier d'Yvoire, M., et al., Ecvam and New Technologies for Toxicity Testing. Advances in experimental medicine and biology, 745, 154-180,2012

10. Dave, S.R., et al., Luminescent Quantum Dots for Molecular Toxicology, in New Technologies for Toxicity Testing. 2012, Springer. p. 117-137.

11. Wakefield, J., Toxicogenomics: Roadblocks and New Directions. Environmental Health Perspectives, 111, 6, A334-A334,2003

12. Aardema, M.J. and J.T. MacGregor, Toxicology and Genetic Toxicology in the New Era of “Toxicogenomics”: Impact of “-Omics” Technologies. Mutation Research/Fundamental and Molecular Mechanisms of Mutagenesis, 499, 1, 13-25,2002

13. Lederberg, J. and A.T. McCray, Ome Sweetomics--a Genealogical Treasury of Words. The Scientist, 15, 7, 8-8,2001

14. Mattingly, C.J., et al., The Comparative Toxicogenomics Database (Ctd). Environmental Health Perspectives, 111, 6, 793-795,2003

15. Budak, Ş.Ö. and S. Dönmez, Gıda Biliminde Yeni Omik Teknolojileri. Gıda Dergisi, 37, 3,

2012

16. Venter, J.C., et al., The Sequence of the Human Genome. science, 291, 5507, 1304-1351,2001

17. Pennie, W.D., Use of Cdna Microarrays to Probe and Understand the Toxicological Consequences of Altered Gene Expression. Toxicology letters, 112, 473-477,2000

18. Schmidt, C.W., Toxicogenomics: An Emerging Discipline. Environmental health perspectives, 110, 12, A750,2002

19. Goetz, A.K., et al., Current and Future Use of Genomics Data in Toxicology: Opportunities and Challenges for Regulatory Applications. Regulatory Toxicology and Pharmacology, 61, 2, 141-153,2011

20. Heijne, W.H.M., et al., Systems Toxicology: Applications of Toxicogenomics, Transcriptomics, Proteomics and Metabolomics in Toxicology. Expert Review of Proteomics, 2, 5, 767780,2005

21. Afshari, C.A., H.K. Hamadeh, and P.R. Bushel, The Evolution of Bioinformatics in Toxicology: Advancing Toxicogenomics. Toxicological Sciences, 120, suppl_1, S225-S237,2010

22. Nuwaysir, E.F., et al., Microarrays and Toxicology: The Advent of Toxicogenomics. Molecular carcinogenesis, 24, 3, 153-159,1999

23. Orphanides, G. and I. Kimber, Toxicogenetics: Applications and Opportunities. Toxicological Sciences, 75, 1, 1-6,2003

24. Jo, Y., et al., Toxpo: Toxicogenomics Knowledgebase for Inferring Toxicity Based on Polymorphism. BioChip Journal, 4, 2, 99-104,2010

25. Irwin, R.D., et al., Application of Toxicogenomics to Toxicology: Basic Concepts in the Analysis of Microarray Data. Toxicologic pathology, 32, 1_suppl, 72-83,2004

26. Aithal, G.P., et al., Association of Polymorphisms in the Cytochrome P450 Cyp2c9 with Warfarin Dose Requirement and Risk of Bleeding Complications. The Lancet, 353, 9154, 717-719,1999

27. Danielson, P., The Cytochrome P450 Superfamily: Biochemistry, Evolution and Drug Metabolism in Humans. Current drug metabolism, 3, 6, 561-597,2002 
28. Waters, M.D. and J.M. Fostel, Toxicogenomics and Systems Toxicology: Aims and Prospects. Nature Reviews Genetics, 5, 12, 936,2004

29. Sturla, S.J., et al., Systems Toxicology: From Basic Research to Risk Assessment. Chemical Research in Toxicology, 27, 3, 314-329,2014

30. Horgan, R.P. and L.C. Kenny, 'Omic’technologies: Genomics, Transcriptomics, Proteomics and Metabolomics. The Obstetrician \& Gynaecologist, 13, 3, 189-195,2011

31. Beyoğlu, D. and J.R. Idle, Metabolomics and Its Potential in Drug Development. Biochemical pharmacology, 85, 1, 12-20,2013

32. Yang, Y., E.A.G. Blomme, and J.F. Waring, Toxicogenomics in Drug Discovery: From Preclinical Studies to Clinical Trials. Chemico-Biological Interactions, 150, 1, 71-85,2004,Khan, S.R., et al., Current Status and Future Prospects of Toxicogenomics in Drug Discovery. Drug discovery today, 19, 5, 562578,2014

33. Kaymak, G., H.E.E. Duruel, and Ş.T. Kizilkaya, Sucul Canlilarin Ekotoksigonenomik Araştırmalardaki Yeri, in Fen Bilimleri Ve Matematik'te Akademik Araştirmalarmatematik'te Akademik Araştırmalar. 2013, Gece Kitaplığı: Ankara. p. 9.

34. Oberemm, A., L. Onyon, and U. Gundert-Remy, How Can Toxicogenomics Inform Risk Assessment? Toxicology and applied pharmacology, 207, 2, 592-598,2005

35. Merrick, B.A., R.S. Paules, and R.R. Tice, Intersection of Toxicogenomics and High Throughput Screening in the Tox21 Program: An Niehs Perspective. International journal of biotechnology, 14, $1,7-27,2015$ 